\title{
Transformation and Integrating of a University Course into a MOOC: An Example in English Teaching
}

\author{
Chunmei YU \\ Public Foreign Language Education College of Beihua University, Jilin, 132013, China \\ email: 943316992@qq.com
}

Keywords: English Film Appreciation; MOOC; SPOC

\begin{abstract}
The development of MOOCs provides a broader space for online courses. Students learn the curriculum in the form of MOOC mainly reflected in course descriptions, course delivery, text messages, picture messages, audio-visual information, job correcting, Q \& A forums and other aspects. This paper presents a practical approach to transform a traditional university course English Film Appreciation into a MOOC. The transformation and integration of a college English course shows the reform and innovation of English Language Teaching under the network and digital background. The aim of having one unique MOOC is to offer a new modern mean of education for our students and help them achieve the effect of traditional classroom learning, at the same time English interactive learning.
\end{abstract}

\section{Introduction}

Language teachers have been using films in their classes for decades, and there are a number of reasons why film is an excellent teaching and learning tool. They let you come back to the characters again and again and predict what will happen to them next. They often reflect real life, which means people in them use real language and grammar. English learners have a big advantage over learners of other languages: Hollywood is in America and it makes English-language movies. There are many websites and blogs which provide detailed and well-structured lesson plans based on film and television clips, short films and videos. Meanwhile MOOCs (Massive Open Online Courses) are emerging all over the world created by universities, associations or even by private companies, provide great opportunities for non-traditional forms of teaching approaches and learner-centred pedagogy where students learn from one another [1]and have opened the eyes of a lot of tutors and policy makers determining them to start rethinking the way courses are being delivered to the students. So with the help of Beijing ChaoXing ErYa Education Technology Co. Ltd., English Film Appreciation Teaching Team of Beihua University took the challenge to create a MOOC from an existing course and co-produced an English language Massive Open Online Course on English Film Appreciation in 2014. [2] A MOOC of English Film Appreciation which is suitable for the English level of Chinese college students and in line with the actual situation of Chinese university was put into use in the spring of 2015. [3]

\section{Experiences}

The experiences gathered during the course building process are divided in three aspects: design, creation and promotion, which are presented as following.

\section{Design}

The purpose of this course is to consolidate the learning outcomes of College English and ensure that college students will not stop learning English during college or in the future. The course also takes into account high school students who are studying English and English film enthusiasts who know English. It will further enhance their English listening and speaking skills, increase their confidence to express their ideas in English, and promote them to improve the ability of using language from a different perspective. The concept of General Education was upheld when designing the curriculum. The classic English film works as a carrier and English as a 
communication tool. Appreciation and analysis are based on artistry and attractiveness of the original works. Students are not only exposed to authentic English, but also equipped with the great intellectual and emotional aesthetic value of the works. Even some grand life propositions were injected in reading and appreciation of the works to improve students' ability of culture and humanity literacy.

Since the excellent English films are too many and this course is expected to play a leading role, the form of the classic theme class is taken. According to the teaching syllabus, 5 films are determined to be the learning contents (Plan to put other selected films on the platform in the form of resource library, total 50). The theme of the curriculum is to experience life through the films and explore the basic qualities of a person who has a meaningful life. 5 units are in the course and the topics are:

$>$ Responsibility. First of all, we should have a sense of responsibility. Just as the father said to his son in The Lion King: "You must take your place in the circle of life."

$>$ Struggle. One's life is to bear their responsibility and work hard. The process of struggle must be hard painful and lonely. as Chris Gardner said in The Pursuit of Happyness: "There is an I in 'happiness'. There is no Y(why) in 'happiness'. It's an I.”

$>$ Perseverance. If we want to insist on, we must have the "fool" spirit of perseverance as Mr. Gump in Forrest Gump. Believe in what Mrs. Gump said: "Stupid is as stupid does."

$>$ Choose. However, should our life be such a no fun experience? Certainly not. So in life, we must learn to choose. Give up we should give up; pursue what we should pursue. To understand this sentence in Avatar: "One life ends, another begins."

$>$ Essence of life. How do we make the right choice? This requires us to know what the true meaning of life is. Remember what Maria said in The Sound of Music: "Whenever I'm feeling unhappy, I just try to think of nice things.”

After watching the movie and listening to the teacher's explanation and inspiration, the students should understand film background, story plot and character feature, imitate pronunciation and intonation, recite the classic expressions used in the film. Master a general way of enjoying English films through the appreciation of music, insights on life and exercises and improve the ability of analysis and comment from two aspects of oral and written English. In order to achieve these teaching objectives, each unit is divided into 10 items on the platform. They are Film Exploration, Music Appreciation, Background Information, Character Introduction, Film Story, Memorable Lines, Insights on Life, Unit Practice, Assignment, Class Task. The course is 32 class hours and 2 credits. The approach has been applied to undergraduate students in Beihua University. About 1000 students in different majors on three campuses have passed this course in the past year. The following is the Course Teaching Plan:

Table 1: Course Teaching Plan

\begin{tabular}{|c|c|c|c|c|c|}
\hline Semester & Contents & Learning style & Class hours & Key words & Pedagogical benefits \\
\hline Week 1 & & & & Preparation & \multirow{14}{*}{$\begin{array}{l}\text { Face-to-face activities: } \\
\text { Learner-centric teaching } \\
\text { Online activities: } \\
\text { Self-paced study } \\
\text { Discussions: } \\
\text { Openness to knowledge } \\
\text { Group work: } \\
\text { Collaboration, participation } \\
\text { Assessments: } \\
\text { Active learning } \\
\text { Project work: } \\
\text { Peer assistance } \\
\text { Feedback: } \\
\text { Instant feedback learning }\end{array}$} \\
\hline Week 2 & Introduction & Face to face & 2 & Participation & \\
\hline Week 3 & \multirow[t]{2}{*}{ The Lion King } & Self-study (Platform) & 3 & \multirow[t]{2}{*}{ Responsibility } & \\
\hline Week 4 & & Face to face (Flip) & 2 & & \\
\hline Week 5 & \multirow{2}{*}{$\begin{array}{l}\text { The Pursuit of } \\
\text { Happyness }\end{array}$} & Self-study (Platform) & 3 & \multirow[t]{2}{*}{ Struggle } & \\
\hline Week 6 & & Face to face (Flip) & 2 & & \\
\hline Week 7 & \multirow[t]{2}{*}{ Forrest Gump } & Self-study (Platform) & 3 & \multirow[t]{2}{*}{ Perseverance } & \\
\hline Week 8 & & Face to face (Flip) & 2 & & \\
\hline Week 9 & \multirow[t]{2}{*}{ Avatar } & Self-study (Platform) & 3 & \multirow[t]{2}{*}{ Choice } & \\
\hline Week 10 & & Face to face (Flip) & 2 & & \\
\hline Week 11 & \multirow{2}{*}{$\begin{array}{l}\text { The Sound of } \\
\text { Music }\end{array}$} & Self-study (Platform) & 3 & \multirow[t]{2}{*}{ Essence of life } & \\
\hline Week 12 & & Face to face (Flip) & 2 & & \\
\hline Week 13 & \multirow{2}{*}{$\begin{array}{l}\text { Review } \\
\text { Test }\end{array}$} & Self-study (Platform) & 3 & \multirow[t]{2}{*}{ Honesty } & \\
\hline Week 14 & & Face to face & 2 & & \\
\hline
\end{tabular}


Face to face class and on line self-study are in turn. Course keeps from Week 2 to Week 14 per semester. Self-study on platform is for 3 class hours every single week and face to face class for 2 class hours is set in a double week. Students are required to declare the task which he/she wants to do after they finish on line self-study and do presentation in face to face class. Teachers will carry out inspection evaluation and summary and deal with the problems and the key difficult points encountered by students in the process of online learning in face to face class.

\section{Creation}

There are three main motivations for having one unique MOOC: it makes it possible to reach the students with the same effort and resources, it opens the possibility for the students to interact and it offers a new learning experience supporting them in their regular work and allowing them to study the course autonomously. Our transformation into a MOOC was done in three steps spread over two years. In a first step, a SPOC (Small Private Online Course) was created and run on-site, to make it possible to test the course before opening it as a MOOC in a second step. [4] The third step was the creation of a new version of the MOOC, which is used for our students on- site and for all the other learners worldwide, at the same time.

This first step offered the possibility for the teaching staffs to learn how to build a MOOC and how to create the videos. Most important of all, course videos should be produced first. 5 parts total 150minutes including Music Appreciation, Background Information, Character Introduction, Film Story, Memorable Lines, Insights on life, each duration 5-7 minutes, was ready in Fall 2014. During the fall of 2014, the SPOC was turned into a MOOC, English Film Appreciation: Classic Theme Class and displayed on the Chaoxing platform. Corrections were also done thanks to the feedback collected after the run of the SPOC. The last step of transformation took place in the spring of 2015 when on-site students were following exactly the course. Specific details are as follows:

Table 2: Course Construction Stage

\begin{tabular}{|c|c|c|c|}
\hline Step & Progress & Duration(m/d/y) & Main Performances \\
\hline 1 & Design & 6/6/2014-6/15/2014 & $\begin{array}{ll}> & \text { Course conception } \\
> & \text { Course material collection } \\
> & \text { Knowledge point division }\end{array}$ \\
\hline 2 & Shooting video & 6/16/2014-8/29/2014 & $\begin{array}{l}\text { Teacher's personal image design } \\
\quad \text { Video shooting according to knowledge point of } \\
\text { curriculum } \\
>\quad \text { Teaching PPT beautification }\end{array}$ \\
\hline 3 & $\begin{array}{l}\text { Video } \\
\text { production }\end{array}$ & 9/1/2014-9/30/2014 & 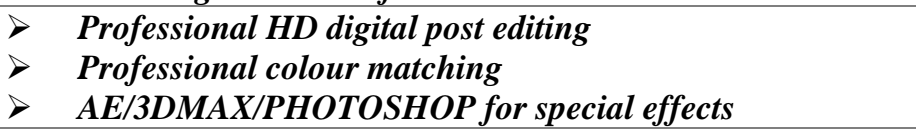 \\
\hline 4 & $\begin{array}{l}\text { Transformation } \\
\text { into a MOOC }\end{array}$ & 10/6/2014-12/30/2014 & $\begin{array}{l}\text { Style and page confirmation } \\
>\quad \text { Course home page editor production } \\
\quad \text { Search process and add the pictures, movie videos, } \\
\text { electronic books required } \\
>\quad \text { Beautification of text layout } \\
>\quad \text { Add related assignments and tests }\end{array}$ \\
\hline 5 & $\begin{array}{l}\text { Submit the } \\
\text { application for } \\
\text { experiment }\end{array}$ & $12 / 10 / 2014-12 / 17 / 2014$ & $\begin{array}{l}\text { The pilot program application of MOOC for Spring } 2015 \\
\text { and obtaining approval }\end{array}$ \\
\hline 6 & Course review & 1/6/2015-2/12/2015 & $\begin{array}{l}\text { Check course contents: videos, pictures, documents, texts, } \\
\text { assignments, tests etc. and update }\end{array}$ \\
\hline 7 & Platform test & $3 / 2 / 2015-3 / 8 / 2015$ & $>\quad$ Test each function module \\
\hline 8 & $\begin{array}{l}\text { Experimental } \\
\text { teaching }\end{array}$ & $\begin{array}{l}3 / 9 / 2015-6 / 6 / 2015 \\
9 / 12 / 2015-12 / 5 / 2015\end{array}$ & $\begin{array}{l}\text { The first round of teaching practice, } 50 \text { students, North } \\
\text { Campus } \\
\text { The second round of teaching practice, } 200 \text { students, } \\
\text { North and East Campuses }\end{array}$ \\
\hline 9 & $\begin{array}{l}\text { Submit formal } \\
\text { application }\end{array}$ & 10/15/2015-10/22/2015 & $\begin{array}{l}\text { The application of MOOC on all campuses for Spring } 2016 \\
\text { and obtaining approval } \\
\quad \text { Teaching syllabus revision }\end{array}$ \\
\hline 10 & Teachers & 12/1/2015-12/16/2015 & Preparation for MOOC on all campuses \\
\hline
\end{tabular}




\begin{tabular}{lllll}
\hline & training & $6 / 15 / 2016-6 / 26 / 2016$ & & \\
\hline $\mathbf{1 1}$ & $\begin{array}{l}\text { Teaching } \\
\text { practice }\end{array}$ & $3 / 12 / 2016-6 / 4 / 2016$ & $>$ & The first round \\
& & $>$ & Summary \\
\hline $\mathbf{1 2}$ & Conclusion & $\mathbf{9 / 1 7 / 2 0 1 6 - 1 2 / 3 / 2 0 1 6}$ & $>$ & The second round \\
& & $>$ & Complete project \\
\hline
\end{tabular}

\section{Promotion}

In order to encourage students to learn actively and consciously, to develop the habit of independent learning, the flipped classroom and performance evaluation are as promotion strategies.

\section{a) Face to face: flipped classroom (more than 100 students,90 minutes)}

There are some who started using MOOCs in a successful symbiosis with their traditional course, embracing blended learning or the flipped classroom concept. Blended learning refers to a formal education program where the student learns at least some parts of the course via the online and digital medium, taking part as well, at some face-to-face classroom sessions. Flipped classroom is a form of blended learning in which the students usually learn the content from someplace else then the school and in the face-to-face meetings they pose questions and solve homework and practical activities. [5] For our course, the main changes are the decrease of the lecture hours and the addition of on-line material. In order to encourage students participating to the MOOC, tasks for class of face to face have been put in place. Flipped classroom focuses on the different activities that our onsite students have to follow. The specific practices see below:

$>$ The Opening, introduction for 5 minutes, is led by the teacher.

$>$ Word Dictation which is the check of the basic task for 10 minutes is also the duty of the teacher. The words and expressions of dictation come from the interpretation of movie lines in Textbook: Part 2, Language Appreciation, Section A Excerpts and Expressions, Selected Scene.

$>$ Talent Show organized by the student host for 10 minutes is to select 2 students PK. Each of them gives an individual performance for 5 minutes. The performance can be an English song or an English poem etc. Talent Show is related to Music Appreciation of the course content.

$>$ Role Play, 10 minutes, organized by the student host, is to act the film clip. Select 2 groups PK and each group has 5 minutes. Roles of each group are determined by the characters in the film clip. Role Play is related to Character Introduction of the course content.

$>$ Film Story Telling, 10 minutes, organized by the student host, is to select 1 student. Use PPT to make a presentation. Film Story Telling is related to Film Story and Background Information of the course content.

$>$ Memorable Lines Reciting is a relay race of writing lines (at least 5 words in a sentence) within 2 minutes for each group, total 5 minutes, organized by the student host. Select 2 groups PK. Memorable Lines Reciting is related to Memorable Lines and movie lines of the course content.

$>$ Film Dubbing, total 10 minutes, organized by the student host, is to choose a film clip for 5 minutes and select 2 groups PK. Group number are determined by the characters in the film clip. Film Dubbing is related to movie lines of the course content.

$>$ Theme Speech, organized by the student host, is an individual performance for 5 minutes. Select 1 student to make a speech. Theme Speech is related to Insights on life of the course content.

$>$ Topic Debate organized by the student host for 5 minutes is to select 2 groups PK. There are 2 persons in each group. Topic Debate can be any subject about the film.

$>$ Concluding remarks, 20 minutes, is the duty of the teacher. Do feedback on assignments and arrange the tasks of the next class.

In order to make flipped classroom achieve better results, extracurricular teaching activity need to be practiced. The student organization can be registered for example English Film Appreciation Association. In the name of the organization, many activities can be organized such as the English Film Dubbing Contest, the English Film Role Play Contest, the English Film Songs Contest and other rich and colourful activities.

\section{b) Evaluation for students (2 credits)}

Another concern is the evaluation of our students and the teacher. Chaoxing platform provides the function of teaching management. The teachers' teaching and students' learning can be 
continuously monitored, checked and given feedbacks in time. Because it is a variety of data generated in the course of teaching, it can be more realistic to reflect the teaching process and students' learning process. On-site students are following the MOOC as part of their university program. Their participation to the MOOC leads to a bonus or penalty for their final grade for the course. On the one hand the teacher can evaluate the students based on their results on the MOOC. On the other hand, our students still have a proctored exam at the end of the course. Consequently, they have to watch the videos because there are no more traditional lectures and they have to make the exercises to get the bonus. Our students also get a bonus/penalty depending on their participation. Having a 100\% mean participation for both MOOC and CLASS results in a +1 bonus, a $50 \%$ mean participation is neutral and a $0 \%$ mean participation leads to a -1 penalty. In short, face to face class may not be absent more than 1/3. Platform self-learning completes at least $85 \%$ on time according to the requirements of online. Take the exam. The final result more than 60 points can be found the corresponding 2 credits.

\section{Expectations}

It is not an easy task to build a MOOC from an existing traditional course. Our course in fact is much like a SPOC as the example in this paper. The following step is an approach by steps not only using the MOOC for our on-site students but also a university-level course. It must also be accessible to worldwide learners who are interested by the material of the course. Through the feedback of our students and of the teaching staffs, future work includes a detailed analysis of those feedbacks in order to improve the MOOC to better satisfy both publics. We are still learning how to use our online platform. The system currently is doing a great job for the grading part, but has still to improve the feedback messages sent back to the learners in case of a wrong answer.

Another improvement that we will work on is to strengthen the interaction between teachers and students on platform. Through interaction teachers can know students' learning situation better. Students can speak freely, in reply to discuss with each other, so as to enhance the understanding and mastery of what they are studying. If students have any problems in the process of self-study or in face-to-face courses, they can launch a discussion to get the answers from the teachers and students in time. For a particularly meaningful one, teachers can make it top and give appropriate guidance to students' discussion. If some students frequently brush some meaningless discussion in order to get high score, teachers should stop them in time. In addition, teachers can also initiate a discussion topic to help the students' mastery of a certain knowledge point. In short, teachers should develop real-time monitoring on the platform.

\section{Conclusion}

This article has presented some of the experiences during the creation of a MOOC: first, introducing the basic information of curriculum; second, explaining some guidelines used during the design, creation and promotion of the course; and, last of all, sharing the expectations. Currently, the first course of English Film Appreciation has been launched; and the film resource library is in progress. The innovative conception behind the MOOC and the process of its creation have offered us an invaluable opportunity to reflect about the way MOOCs offer some answers to the challenges of the Chinese higher education system today. Maybe as Riddle says the most obvious use for an open course is promoting the university itself, giving the public an idea of the current state of inquiry and research in a particular field. [6]

\section{Acknowledgement}

This work was partially supported by Beihua University (Project No. [2014]113) and Education Department of Jilin Province (Project NO. [2015]75). 


\section{References}

[1] Dron, J. and T. Anderson. "Teaching crowds: Social media and distance learning.", AU Press, 2014. Fisher, D. (2012). Warming up to MOOCs. Chronicle of Higher Education (Nov. 6, 2012).

[2] Course website: http://mooc.chaoxing.com

[3] http://www.jledu.gov.cn/show/27799.html/2015-04-10

[4] Combéfis, S., Bibal, A., \& Van Roy, P. (2014). Recasting a traditional course into a MOOC by means of a SPOC. In Proceedings of The European MOOCs Stakeholders Summit 2014, 205-208.

[5] C. Holotescu, G. Grosseck, V. Cretu, Naaji, A. (2014) “Integrating MOOCs in Blended Courses”. 10th International Scientific Conference eLearning and Software for Education, Bucharest, Romania, ISSN 2066 - 026X, 2014.

[6] Riddle, R. (2012). MOOCs: What role do they have in higher education?. Retrieved at http://cit.duke.edu/blog/2012/09/moocs-what-role-do-they-have-in-higher-education/ (last accessed 22.01.2015) Sandeen, C. (2013). Integrating MOOCS into Traditional Higher Education: The Emerging “MOOC 3.0” Era. Change: The Magazine of Higher Learning,45(6), 34-39. 